\title{
Metazoan parasite of lambari Astyanax altiparanae, collected from the Peixe river, São Paulo, southeast of Brazil
}

\author{
Metazoários parasitos de lambari Astyanax altiparanae, coletados \\ do rio do Peixe, São Paulo, sudeste do Brasil
}

\begin{abstract}
Aline de Almeida Camargo ${ }^{\mathrm{I}}$ Débora Caroline Negrelli ${ }^{\mathrm{II}}$ Natacha Heloísa Olavo Pedro Rodney Kozlowiski de Azevedo ${ }^{\text {II }}$ Reinaldo José da Silva ${ }^{I I I}$ Vanessa Doro Abdallah ${ }^{\text {II }}$
\end{abstract}

ABSTRACT

In March 2010, 44 specimens of Astyanax altiparanae Garutti \& Britski, 2000, commonly known as "lambari do rabo amarelo", collected from the Peixe river in the state of São Paulo, Brazil were analyzed. Out of these 44 fishes, 38 had at least one species of metazoan parasite. Fifteen metazoan parasites species were collected and identified: Urocleidoides trinidadensis, Diaphorocleidus kabatai, Diaphorocleidus orthodusus, Diaphorocleidus $s p$., Urocleidoides $s p$., Trinibaculum altiparanae, Gyrodactylus sp., Jainus hexops, Contracaecum sp., Procamallanus (Spirocamallanus) inopinatus, Vaigamus $s p$. ., Amplexibranchius bryconis, Ergasilus sp., Zonocotyloides haroltravassossi and Henneguya sp. Six species of parasites presented a prevalence of over 10\%. Weight and length of fishes didn't influence the parasitism. All parasites presented an aggregated distribution. The parasite community of Astyanax altiparanae from the Peixe river was characterized as having high richness and low uniformity.

Key words: Astyanax altiparanae, lambari, Peixe river, parasite, Brazil. RESUMO

Em março de 2010, foram coletados e analisados 44 espécimes de Astyanax altiparanae Garutti \& Britski, 2000, conhecidos popularmente como lambari do rabo amarelo, provenientes do rio do Peixe, Estado de São Paulo, Brasil. Dos 44 peixes analisados, 38 estavam parasitados por pelo menos uma espécie de metazoário parasito. Quinze espécies de metazoários parasitos foram coletadas e identificadas: Urocleidoides trinidadensis, Diaphorocleidus kabatai, Diaphorocleidus orthodusus, Diaphorocleidus sp., Urocleidoides sp., Trinibaculum altiparanae, Gyrodactylus sp., Jainus hexops, Contracaecum sp., Procamallanus (Spirocamallanus) inopinatus, Vaigamus sp., Amplexibranchius bryconis, Ergasilus sp., Zonocotyloides haroltravassossi e Henneguya sp. Os parasitos D. kabatai, $\boldsymbol{U}$. trinidadensis, J. hexops, $\boldsymbol{P}$. (S.) inopinatus e Vaigamus sp. apresentaram prevalências superiores a 10\%. O peso e o comprimento dos peixes não influenciaram no parasitismo. Todos os parasitos apresentaram distribuição agregada. A comunidade parasitária de Astyanax altiparanae proveniente do rio do Peixe foi caracterizada por alta riqueza e baixa uniformidade.

Palavras-chave: Astyanax altiparanae, lambari, rio do Peixe, parasitos, Brasil.

\section{INTRODUCTION}

Astyanax altiparanae Garutti \& Britski, 2000, commonly known as "lambari do rabo amarelo", has a horizontally oval black humeral spot and a diamond-shaped black spot in the caudal peduncle (GARUTTI \& BRITSKI, 2000). It's a small size specimen that can get to between 10 and 15 centimeters long. It has an omnivorous feeding behavior; feeding mainly on superior vegetables, insects and copepods. Male and female adults can get to different sizes. The males are usually smaller and get to between 7 and 12 centimeters long and the females are bigger and get to between 12 and 15 centimeters long (PORTO-FORESTI et al., 2001). According to ORSI \& SUZUKI (2008), two types

\footnotetext{
IPrograma de Pós-graduação em Ciências Biológica, (Zoologia), Instituto de Biociências, Universidade Estadual Paulista (UNESP), Botucatu, SP, Brasil.

IIUniversidade do Sagrado Coração, Rua Irmã Arminda, 10-50, Jardim Brasil, 17011-160, Bauru, SP, Brasil. E-mail: vanessaabdallahusc@gmail.com. *Corresponding author.

IIIDepartamento de Parasitologia, Instituto de Biociências, Universidade Estadual Paulista "Júlio de Mesquita Filho" (UNESP), Botucatu, SP, Brasil.
} 
of shoals origin from the A. altiparanae specimens; the bigger ones are formed by approximately 50 individuals in their young stage, and the smaller ones are formed by approximately 15 individuals in their adult stage. The formation of groups; however, may have some negative aspects, such as a great amount of parasites transfer.

The parasites perform key-functions in the ecosystems, controlling the abundance or density of host populations, which keep the food chain stable and also structure the animal communities. Thus, the parasites, in the last few years, have been considered an important element of the global biodiversity (POULIN \& MORAND, 2004).

The Peixe river is one of the left-bank tributaries of the middle Tietê river basin in the Barra Bonita area. Regarding the hydrography, this river has its sources located in the city of Torre de Pedra (São Paulo) in an area along with the Environmental Preservation Area (EPA) of the Basaltic Cuesta of Botucatu, with a $584 \mathrm{~km}^{2}$ drainage-basin in the direction to the north-south axis. According to CARAMASCHI (1986), this river presents a strong altitudinal gradient with a $70 \mathrm{~m}$ altitude gap up to $430 \mathrm{~m}$ at its mouth in Barra Bonita, in the municipal area of Anhembi (São Paulo).

Different studies have been carried out with $A$. altiparanae, from which can be pointed out: BARASSA et al. (2003), who described Henneguya chydadea parasitizing this host in a lake in the Pedras river, State of São Paulo; FERRARI-HOEINGHAUS et al. (2006), who studied the monogenean parasites of A. altiparanae and Rhamdia quelen in the São Francisco Verdadeiro River; PAVANELLI et al. (2006), who did a metazoan parasite study of $A$. altiparanae in the Paraná River floodplain; AZEVEDO et al. (2007), who conducted a helminth fauna study of this host in lakes and ponds of the rio das Pedras Farm, Campinas, São Paulo, analyzing the influence of different water bodies and the sex of host parasitism; LIZAMA et al. (2008), who conducted an ecological study of the metazoan parasites of $\boldsymbol{A}$. altiparanae in the Paraná River floodplain, identifying 23 species; ALMEIDA \& COHEN (2011), who studied the monogeneans of $\boldsymbol{A}$. altiparanae in net-tanks in the reservoir of Itaipu Hydroelectric Power Plant and of the Paraná river; ABDALLAH et al. (2012) studied the nematode of this species in the Peixe river, São Paulo; ABDALLAH et al. (2013), who described the monogenean Trinibaculum altiparanae, parasitizing the gills of the host in the Peixe river, São Paulo, among others.

The purpose of this study was to identify the parasitic fauna of $\boldsymbol{A}$. altiparanae of the Peixe river and to carry out its quantitative analysis; thus, contributing to the knowledge of the biodiversity of the aquatic environment within the state of São Paulo.

\section{MATERIAL AND METHODS}

Specimens of $\boldsymbol{A}$. altiparanae were collected in March 2010 in the Peixe river $\left(48^{\circ} 06^{\prime} 38^{\prime \prime} \mathrm{W}\right.$; $22^{\circ} 49^{\prime} 53.1$ 'S) with trawls of different meshes. Fishes were identified according to GARUTTI \& BRITSKI (2000). After collected, the fishes were stored individually and taken to the Laboratório de Parasitologia de Animais Silvestres (LAPAS) at the Universidade Estadual Paulista "Júlio de Mesquita Filho" (UNESP) in the campus of Botucatu, where they were examined and had their biometric data taken. Body surface, gills and nostrils were examined to search for ectoparasites. By means of an incision in the ventral region of the hosts, all organs were removed and analyzed using a stereomicroscope to collect endoparasites. Techniques of EIRAS et al. (2000) were followed to the preparation, mounting and fixation of metazoan parasites.

Calculus of prevalence, mean abundance and mean intensity of parasitism were carried out according to BUSH et al. (1997). Ratio between variance and mean (dispersion indices) was used in each species of parasite to indicate whether the infections were aggregated and determine their type of distribution. The statistical $d$ was also calculated to evaluate their significance (LUDWIG \& REYNOLDS, 1988). Frequency of dominance and mean relative dominance (number of specimens of the same species/total number of specimens of all species of infra community) were calculated for each parasite species (ROHDE et al., 1995). Spearman's rank correlation coefficient $\left(r_{s}\right)$ was used for the analysis of possible correlations between the host weight and parasite abundance, and between standard host length and parasite abundance. The aforementioned tests were applied only to those species of parasites that presented prevalence greater than $10 \%$ (BUSH et al., 1990). The indices of Brillouin (H), Pielou (J') and Margalef(d) were used to evaluate, respectively, the diversity, uniformity and parasite richness

Representative specimens of the species of parasites were deposited in the Helminthological Collection of the Instituto de Biociências at Universidade Estadual Paulista “Júlio de Mesquita Filho" (UNESP) in the campus of Botucatu.

\section{RESULTS AND DISCUSSION}

A total of fifteen species of metazoan parasites was collected (Table 1). The monogeneans 
Table 1 - Prevalence, mean abundance, mean intensity and site of infection of the metazoan parasite in Astyanax altiparanae Garutti and Britski, 2000, from the Peixe river, SP, Brazil.

\begin{tabular}{|c|c|c|c|c|}
\hline Parasites & Prevalence (\%) & Mean abundance & Mean antensity & Site of infection/ infestation \\
\hline \multicolumn{5}{|l|}{ Myxozoa } \\
\hline Henneguya sp. & 13.64 & - & - & Gills \\
\hline \multicolumn{5}{|l|}{ Monogenea } \\
\hline Diaphorocleidus kabatai & 47.72 & 3.14 & 6.57 & Gils \\
\hline Diaphorocleidus orthodusus & 4,54 & 0.07 & 1.50 & Gills \\
\hline Diaphocleidus sp. & 4.54 & 0.16 & 3.50 & Nostril \\
\hline Gyrodactylus sp. & 4.54 & 0.07 & 1.50 & Gills \\
\hline Jainus hexops & 11.36 & 0.27 & 2.40 & Gills \\
\hline Trinibaculum altiparanae & 2.27 & 0.14 & 6.00 & Gills \\
\hline Urocleidoides sp. & 6.82 & 0.14 & 2.00 & Gills \\
\hline Urocleidoides trinidadensis & 27.27 & 1.02 & 3.75 & Gills \\
\hline \multicolumn{5}{|l|}{ Digenea } \\
\hline Zonocotyloides haroltravassossi & 2.27 & 0.02 & 1.00 & Intestine \\
\hline \multicolumn{5}{|l|}{ Nematoda } \\
\hline Contracaecum sp. & 4.54 & 0.05 & 1.00 & Intestine \\
\hline Procamallanus (Spirocamallanus) inopinatus & 22.73 & 0.36 & 1.60 & Stomach and Intestine \\
\hline \multicolumn{5}{|l|}{ Crustacea } \\
\hline Amplexibranchius bryconis & 2.27 & 0.25 & 11.00 & Gills \\
\hline Ergasilus sp. & 6.82 & 0.14 & 2.00 & Gills \\
\hline Vaigamus sp. & 11.36 & 0.23 & 2.00 & Gills and liver \\
\hline
\end{tabular}

represented the majority of the specimens collected $(82.71 \%)$, followed by the crustaceans $(10.15 \%)$, nematodes $(6.77 \%)$ and digeneans $(0.37 \%)$.

The monogenean Diaphorocleidus kabatai was the predominant parasite species, with 138 collected specimens representing $51.88 \%$ of the total parasites collected (266) and it presented the highest value of dominance frequency (Table 2). The parasites presented an aggregate distribution pattern (Table 3). The length and weight of the hosts did not influence the parasitism of $\boldsymbol{A}$. altiparanae.

From all 44 specimens of $A$. altiparanae collected, 38 were parasitized by at least one species of

Table 2 - Frequency of dominance (\%) and relative dominance of metazoan parasites of Astyanax altiparanae from the Peixe river, SP, Brazil.

\begin{tabular}{lcc}
\hline Parasites & $\begin{array}{c}\text { Frequency of } \\
\text { Dominance (\%) }\end{array}$ & $\begin{array}{c}\text { Relative } \\
\text { Dominance }\end{array}$ \\
\hline $\begin{array}{l}\text { Diaphorocleidus kabatai } \\
\text { Jainus hexops }\end{array}$ & 40.91 & $0.52 \pm 5.83$ \\
$\begin{array}{l}\text { Procamallanus } \\
\text { (Spirocamallanus) } \\
\begin{array}{l}\text { inopinatus } \\
\text { Urocleidoides } \\
\text { trinidadensis }\end{array}\end{array}$ & 9.09 & $0.04 \pm 0.92$ \\
Vaigamus sp. & 11.36 & $0.06 \pm 0.78$ \\
\hline
\end{tabular}

metazoan parasite, with a mean of six parasites/fish. Six hosts (13.64\%) were not parasitized, 14 hosts (31.82\%) were parasitized by one species, $16(36.36 \%)$ were parasitized by two species, four $(9.09 \%)$ were parasitized by three species, two hosts $(4.54 \%)$ were parasitized by four species of parasites and two hosts $(4.54 \%)$ by five species of parasites. The total number of parasites showed no positive correlation with the total length of $\boldsymbol{A}$. altiparanae ( $r s=0.16, P=0.31$ ) and did not show any significant results regarding the weight of the host ( $r s=0.08, P=0.60$ ). The parasite species richness showed no significant correlation with the total length of hosts $(r s=0.06, P=0.71)$ and no significant result regarding the weight of the host $(r s=-0.02, P=0.91$ ). The mean richness was $1.39 \pm 1.24$, the mean uniformity was $0.70 \pm 0.38$ and the mean diversity was $0.76 \pm 0.75$.

Table 3 - Values of index dispersion (ID) and statistical $d$ test of metazoan parasites of Astyanax altiparanae from the Peixe river, SP, Brazil.

\begin{tabular}{lll}
\hline Parasites & \multicolumn{2}{c}{ ID } \\
\hline Diaphorocleidus kabatai & 10.82 & 21.29 \\
Jainus hexops & 3.13 & 7.20 \\
Procamallanus (Spirocamallanus) inopinatus & 1.69 & 2.84 \\
Urocleidoides trinidadensis & 4.20 & 9.79 \\
Vaigamus sp. & 2.99 & 6.82 \\
\hline
\end{tabular}


Results obtained in this study indicated that the parasitic community of A. altiparanae from the Peixe river was characterized by high richness and low uniformity. According to BUSH et al. (1997), diversity is the concept that describes a community composition in terms of number of species and some factor that weights the relative equality in the distribution of each species. There is no environment where all species are equally common; some are abundant, others are moderately common and most are rare. Biodiversity can be divided into two components: species richness that stands for the number of species present in a sample and uniformity (equitability) that describes the variability in the abundance of species. A community in which all the species have approximately the same number of individuals can be considered very uniform, while a large disparity in the relative amount of species results in a low uniformity (MAGURRAN, 1988). Communities with high species richness, uniformity or both are generally considered as more diverse (PIELOU, 1977). According to what has been previously exposed, the results reported indicated that the parasitic community of $\boldsymbol{A}$. altiparanae presents high variability in amount of species and high species richness.

The length of the host, considered to be an expression of its age, is one of the key factors in size variation of infrapopulations of parasites (DOGIEL, 1961). However, in this study, the length of the host did not influence the parasite abundance, which may suggest regarding the endoparasites, that the food items in the different age groups must be similar and there must be no variation in use of this species habitat and regarding the ectoparasites, that the availability of the infecting forms must be similar in the different age groups of these fish.

The parasites reported in $\boldsymbol{A}$. altiparanae presented an aggregated species distribution pattern. This pattern is considered typical of the parasites found in freshwater fish. According to ZUBEN (1997), the aggregated distribution pattern acts in order to increase the regulation which depends of the density and abundance of both hosts and parasites, aside from reducing the level of interspecies competition among the parasites.

The D. kabatai species presented the highest prevalence value among the parasites found in this study, though the monogenetic parasite $\boldsymbol{J}$. hexops and $\boldsymbol{U}$. trinidadensis were also reported with prevalence values higher than $10 \%$. Astyanax altiparanae monogenetic parasites of the Peixe river represented $82.71 \%$ of the total of metazoans reported. High intensity of infestation by ectoparasites can be explained due to the fact that the $A$. altiparanae specimens form shoals both in the young and adult stages, making the transference of these parasites easier (ORSI \& SUZUKI, 2008). Monogenetic parasites are hermaphrodites and present a direct life cycle; therefore, where there is a high concentration of individuals, the parasite finds it easy to complete his life cycle. The monogenetic parasites were reporeted mostly in the gills, and its presence may provoke an excessive production of mucus leading the host to death by asphyxia (PAVANELLI et al., 2002).

There are two ecological studies which were carried out with the species $A$. altiparanae: LIZAMA et al. (2008) that performed a study in the Paraná River's floodplain and AZEVEDO et al. (2007) whose study was performed at Pedras river farm, Campinas, São Paulo. LIZAMA et al. (2008) registered 23 metazoan parasite species in this host, the endoparasite fauna being represented by $97.42 \%$ of the total collected parasites. In the study of AZEVEDO et al. (2007), six species of metazoan parasites were registered, most of them being endoparasites. The results of those two studies differ from those obtained in our study, since the ectoparasites represented most of the parasites collected. This may be explainable, since in environments with medium currents and low depths, like the Peixe river, the ciliated larvae of the monogenic parasites (oncomiracidium) can find their hosts more easily, which in lentic environments with great depths such as the lake located on the rio das Pedras farm and floodplain of the Paraná River, turn meeting between the larva and the fish more difficult.

Regarding the endoparasites, in environments with currents, the crustacean and the mollusks (intermediate hosts) are not easily reported like in lentic environments, and; therefore, this might explain the low amount of endoparasites reported in this study.

\section{CONCLUSION}

This study indicated that the parasitic community of $\boldsymbol{A}$. altiparanae from the Peixe river was characterized by high richness and low uniformity. With the exception of D. kabatai, T. altiparanae, Urocleidoides sp., U. trinidadensis and $\boldsymbol{Z}$. haroltravassossi, all other parasites are being registered in this host for the first time. 


\section{ACKNOWLEDGMENTS}

The authors would like to thank Leila Felipini for editing the English. Vanessa D. Abdallah was supported by a student fellowship from FAPESP (2009/51726-6), Rodney K. de Azevedo was supported by a student fellowship from Fundação de Amparo À Pesquisa do Estado de São Paulo (FAPESP) (2010/06564-5) and Reinaldo José da Silva was supported by a research fellowship from Conselho Nacional de Desenvolvimento Científico e Tecnológico (CNPq) (312590/2009-1) and FAPESP (2009/53316-0).

\section{REFERENCES}

ABDALLAH, V.D. et al. New hosts and distribution records for nematodes parasites of freshwater fishes form São Paulo State, Brazil. Neotropical Helmintology, v.6, n.1, p.43-57, 2012. Available from: $<$ http://sisbib.unmsm.edu.pe/bvrevistas/neohel/v6n1/pdf/a05v06n1 pdf $>$. Accessed: Jul. 08, 2015.

ABDALLAH, V.D. et al. Trinibaculum altiparanae sp. n., a new Dactylogyrid species (Monogenea) of the Astyanax altiparanae (Osteichthyes: Characidae) in the Peixe river, Southeastern Brazil. Neotropical Helmintology, v.7, n.2, p.211-217, 2013. Available from: $<$ http://sisbib.unmsm.edu.pe/bvrevistas/neohel/v7n2/pdf/a04v7n2. pdf $>$. Accessed: Jul. 08, 2015.

ALMEIDA, K.S.S.; COHEN, S.C. Diversidade de Monogenea (Platyhelminthes) parasitos de Astyanax altiparanae do reservatório da usina hidrelétrica de Itaipu. Revista Saúde \& Ambiente, v.6, n.1, p.31-41, 2011. Available from: $<$ http://publicacoes.unigranrio.br/index.php/sare/article/ viewFile/1316/753>. Accessed: Jul. 08, 2015.

AZEVEDO, G.B. et al. Metazoários parasitas de Astyanax altiparanae (Pisces: Characidae) na Fazenda Rio das Pedras, Campinas, SP, Brasil. Revista Bioikos, v. 21, n.2, p. 89-96, 2007. Available from: $<$ http://periodicos.puc-campinas.edu.br/seer/index.php/bioikos/article/ view/844/823>. Accessed: Jul. 08, 2015.

BARASSA, B. et al. A new species of Henneguya, a gill parasite of Astyanax altiparanae (Pisces: Characidae) from Brazil, with comments on histopathology and seasonality. Memórias do Instituto Oswaldo Cruz, v.98, n.6, p.761-765, 2003. Available from: <http://memorias.ioc.fiocruz.br/issues/ special-issues/item/2132>. Accessed: Jul. 08, 2015.

BUSH, A.O. et al. Ecological versus phylogenetic determinants of helminth parasite community richness. Journal Evolutionary Ecology, v.4, n.1, p.1-20, 1990. Available from: <http://link.springer. com/article/10.1007\%2FBF02270711>. Accessed: Jul. 08, 2015. doi: 10.1007/BF02270711.

BUSH, A.O. et al. Parasitology meets ecology on its own terms: Margolis et al., revisited. Journal of Parasitology, v.83, n.4, p.575-593, 1997. Available from: <http://www.fcfar.unesp.br/arquivos/494986 pdf>. Accessed: Jul. 08, 2015. doi: 10.2307/3284227.

CARAMASCHI, E.P. Distribuição da ictiofauna de riachos das Bacias do Tietê e do Paranapanema, junto ao divisor de águas (Botucatu, SP). 1986. 245f. Tese (Doutorado em Ciências) Universidade Federal de São Carlos, SP.

DOGIEL, V.A. Ecology of the parasites of freshwater fishes. In: DOGIEL, V.A. et al. (Ed.). Parasitology of fishes. (Translated by Z. Kabata). Edinburgh; London: Oliver and Boyd, 1961. Cap.1, p.1-47.
EIRAS, J.C. et al. Métodos de estudo e técnicas laboratoriais em parasitologia de peixes. Maringá: Universidade Estadual de Maringá, 2000. 500v, 171p

FERRARI-HOEINGHAUS, A.P. et al. Host-parasite relationships of monogeneans in gills of Astyanax altiparanae and Rhamdia quelen of the São Francisco verdadeiro river, Brazil. Journal Parasite, v.13, n.4, p.315-320, 2006. Available from: <http:// www.parasite-journal.org/articles/parasite/pdf/2006/04/ parasite2006134p315.pdf $>$. Accessed: Jul. 08, 2015.

GARUTTI, V.; BRITSKI, H.A. Descrição de uma espécie nova de Astyanax (Teleostei: Characidae) da bacia do alto rio Paraná e considerações sobre as demais espécies do gênero na bacia. Comunicações do Museu de Ciência e Tecnologia, v.13, p.65-88, 2000.

LIZAMA, M.L.A.P. et al. Ecological aspects of metazoan parasites of Astyanax altiparanae GARUTTI \& BRITSKI, 2000 (Characidae) of the upper Paraná river floodplain, Brazil. Boletim do Instituto de Pesca, v.34, n.4, p.527-533, 2008. Available from: <ftp://ftp.sp.gov.br/ ftppesca/34_4_527-533.pdf $>$. Accessed: Jul. 08, 2015.

LUDWIG, J.A.; REYNOLDS, J.F. Statistical ecology: a primer on methods and computing. New York: John Wiley \& Sons, 1988. 337p.

MAGURRAN, A.E. Ecological diversity and its measurement. New Jersey: Princeton University, 1988. 179p.

PAVANELli, G.C. et al. Doenças de peixes. Profilaxia, diagnóstico e tratamento. 2.ed. Maringá: Universidade Estadual de Maringá, 2002. 305p.

PAVANELLI, G.C. et al. Ano Ictioparasitologia. In. UNIVERSIDADE ESTADUAL DE MARINGÁ. Nupélia/ PELD. A planície de inundação do Alto rio Paraná: Site 6 PELD/CNPq-Relatório anual 2006. Available from: <http:// www.peld.uem.br/Relat2006/pdf/12_Ictioparasitologia.pdf $>$. Accessed: Jul. 08, 2015

PIELOU, E.C. Mathematical ecology. New York: Willey, 1977. 385p.

PORTO-FORESTI, F. et al. Cultivo do lambari: uma espécie de pequeno porte e grandes possibilidades. Panorama da Aquicultura, v.11, n.67, p.15-19, 2001.

POULIN, R.; MORAND, S. Parasite biodiversity. Washington, D.C.: Smithsonian Books, 2004. 216p

ROHDE, K. et al. Aspects of the ecology of metazoan ectoparasites of marine fishes. International Journal for Parasitology, v.25, n.8 p.945-970, 1995. Available from: <http://www.ncbi.nlm.nih. gov/pubmed/8550295>. Accessed: Jul. 08, 2015.

SUZUKI, F.M.; ORSI, ML. Formação de cardumes por Astyanax altiparanae (Teleostei: Characidae) no Rio Congonhas, Paraná, Brasil. Revista Brasileira de Zoologia, v.25, n.3. p.566-569, 2008. Available from: <http://www.scielo.br/scielo.php?pid=S010181752008000300026\&script $=$ sci_arttext $>$. Accessed: Jul. 08, 2015. doi: 10.1590/S0101-81752008000300026.

ZUBEN, C.1. Implicações da agregação espacial de parasitas para dinâmica populacional na interação hospedeiroparasita. Revista Saúde Pública, v.31, n.5, p.523-530, 1997. Available from: <http://www.scielo.br/scielo.php?pid=S003489101997000600014\&script $=$ sci arttext $>$. Accessed: Jul. 08, 2015. doi: 10.1590/S0034-89101997000600014. 